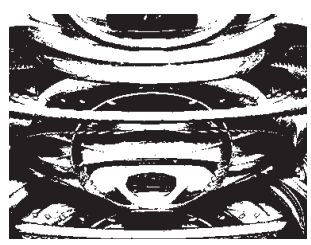

\title{
EXPERIENCING DALMATIA: WHAT CONSTITUTES THE SENSORY LANDSCAPE IDENTITY OF THE DALMATIA REGION?
}

Maja KLJENAK

Zadar

Slavko KURDIJA

Faculty of Social Sciences, Ljubliana

Marko POLIČ

Faculty of Arts, Ljubljana

Mojca GOLOBIČ

Biotechnical Faculty, Ljubliana

UDK: 712(497.5-3Dalmacija) 316.654:711.2(497.5-3Dalmacija)

Izvorni znanstveni rad

Primljeno: 4. 4. 2013.

The article addresses the concept of landscape identity considered from a new perspective - a perspective of five fundamental human senses: sight, hearing, smell, touch and taste. Landscape identity is mostly understood as a phenomenon based on its distinguishable visual characteristics. However, human environment is a multisensory medium, rich in information from all fields of perception. Equally, a man is a multisensory being and experiences his environment with multiple senses. The underlying assumption is that human identification with places does not only arise from the interaction with their visual, but also with their auditory, olfactory, tactile, and even gustatory properties. As a research area, the Dalmatia region in Croatia has been chosen. By the content analysis method, applied on samples of lyric poems and promotional (mostly tourist) materials, the aim was to examine what features, visual and non-visual, the social conception of Dalmatian landscape is based on. The results show that landscape identity of Dalmatia, in terms of sensory perception, is rather diverse. Understanding landscape identity as a sensory multidimensional phenomenon opens many new questions and possibilities in the field of landscape theory and practice.

Keywords: landscape, environmental perception, senses, sensory landscape identity, Dalmatia 


\section{INTRODUCTION}

Human cognition of space depends largely on the senses. The process of their evolution reflects conditions and changes of the human environment, with the principal goal of enabling successful survival in given circumstances (Polic, 2007). Accordingly, people are able to perceive only a small part of the unlimited range of stimuli in their surroundings, and that what is available to their senses is what Gibson (1986) calls ecological space. He conceives the environment as composed of inanimate things and substances, living organisms and various occurrences and events, and it is characterised by an enormous diversity of sensory "information". He argues that: "We all behave with respect to things we can look at and feel, or smell and taste, and events we can listen to." (Gibson, 1986, p. 9). The concept of ecological space, regarding environment as a holistic living medium with all that can be perceived in it, is appropriate and, therefore, accepted in this paper. It gives a valid frame for the research of different sensory components of landscape, not only the visual one.

Respecting the assumption that a person experiences their environment through all senses and that those experiences form their attitudes, emotions, and behaviour, this research departs from the hypothesis that landscape identity comprises different sensory characteristics of place. In short, it is assumed to be based on specific sounds, smells, tactile sensations and tastes, as well as on specific sights. To verify this hypothesis, the Dalmatia region in Croatia was chosen. The fundamental research question is: do non-visual landscape features have their place in the spatial identity of Dalmatia and to what extent?

\section{SENSES AND LANDSCAPE EXPERIENCE}

It is often stated that sight is, especially in western culture, the most important sense in the hierarchy of human perception (see Borthwick, 2000; Classen, 1990, 1997; Everett, 2008; Macpherson, 2006; Pallasmaa, 2005; Paterson, 2007, 2009; Rodaway, 1994; Sui, 2000; Tuan, 1990). Dealing with space, interior or exterior, has mostly been focused on its visual qualities both in theory and practice, while other sensory properties have been rather disregarded. However, environment is far more than just visible surrounding. Due to our senses, it is experienced through sounds, smells, tactile sensations and tastes. These aspects constitute the complex and changeable sensory composition of the perceivable world.

Non-visual ${ }^{1}$ experiences have an important role in everyday human contact with landscape. Firstly, they significantly contribute to the understanding of spatial organisation and 
DRUŠ. ISTRAŽ. ZAGREB GOD. 22 (2013), BR. 2 STR. $277-302$

KLJENAK, M. ET AL. EXPERIENCING... order and to orientation skills (Casey, 1993; Gardiner \& Perkins, 2005; Kitchin, Blades, \& Golledge, 1997; Rodaway, 1994). Consequently, says Golledge (1992), they provide a sense of security. Lynch (1960) is also inclined to assume that way-finding is not instinctive, but rather a result of consistent use and organisation of the information contained in environmental stimuli. Spatial decisions and behaviour depend sometimes on non-visual stimulus. An illustrative example comes from everyday urban life, where by relying largely on sounds we can better discern traffic situations. Furthermore, non-visual perception can be vital to the blind and visually impaired (Gardiner \& Perkins, 2005) and to those with some other disabilities.

Secondly, auditory, olfactory, tactile and even gustatory properties, just like the visual ones, represent aesthetic values of landscape. Beside sights (or despite them), the impression and characteristic atmosphere of place is often defined by sounds or smells. They can be appealing or repulsive, for example a noise or the smell of garbage. In considering the qualities of the natural ambience of the Split seafront, Mišetić (1997) regarded noise as one of the pollutants that diminishes the harmony and atmosphere of the site. Non-visual experiences, thus, complement the overall sense of place and affect the way we feel in them. The feeling of relaxation, which Mišetić connects with the Split seafront area, is a typical example of an emotional welfare that landscape can provide. It is understandable that in some places we feel more pleasant than in others, but it is not always and entirely due to their visual features. Landscape provides aesthetic and emotional experience as a mosaic of sensations of different sensory modalities (Hough, 1990; Moore \& Whelan, 2007; Tuan, 1990).

\section{SENSORY DIMENSIONS OF LANDSCAPE IDENTITY}

The concept of landscape identity seems clear enough and unambiguous. For most laypeople and experts it has visual connotations, implying distinguishable features of visible landscape. However, memories of a certain place, whether they are evoked by reflection or by random stimulus, are sometimes more strongly connected with its sounds or smells than with its sights. A famous example is a series of involuntary memories of the main character in Marcel Proust's book In Search of Lost Time: Swann's Way, induced by the taste and smell of a madeleine cookie. Therefrom logically follows the assumption that visual characteristics are not the only attributes by which people identify, value and remember the landscape. Their relationship with landscape is also defined through auditory, olfactory, tactile and gustatory experiences. 
DRUŠ. ISTRAŽ. ZAGREB GOD. 22 (2013), BR. 2, STR. 277-302

KLJENAK, M. ET AL.: EXPERIENCING..
In the last half century, there has been a slight increase of interest for non-visual landscape properties in professional and scientific work. They are usually addressed individually - focusing on one particular sensory modality. Of all the non-visual properties, sound is the most examined one, and often in context of noise pollution. Also, numerous gastronomy and culinary books and TV shows prove a great interest in gustatory characteristics of places. The connection between gustatory perception and landscape may be less obvious and direct, but it certainly exists. Namely, food and foodstuffs of a region are conditioned by landscape characteristics (relief, climate, soil) and culture. Food is closely related to a local environment, states Counihan (1999). Visočnik (2005, p. 14), for example, emphasizes the use of seasonal ingredients (shun or "now-in-season") as one of the key principles of Japanese cuisine. Foodstuffs available in the close environment and dishes made from them reflect to a certain degree gustatory qualities and the character of landscape.

Non-visual qualities are rarely considered as properties of landscape identity. Valuable contribution in this sense (regarding sounds) is a project named Sound Landscape and Intangible Territories ${ }^{2}$ and papers arising therefrom. They are primarily concerned with identification of characteristic sounds and soundscapes in Catalonia (see Observatori del Paisatge de Catalunya, 2009; The Landscape Observatory of Catalonia, 2013). Furthermore, Anzani (2010) revealed that ringing of the bells from numerous church towers creates a distinguishable soundscape and auditory landscape identity of the Monte Stella community in southern Italy (in Salerno, Campania region). In his research, the bell sound was extracted as a sonic characteristic of the area, but it does not mean it is the only one. Auditory identity can comprise various sounds that usually occur in the landscape. Social perception of a visible landscape is studied relatively often. In contrast, there are few studies (or none at all) examining, for example, what group of sounds or smells constitute auditory or olfactory landscape identity. The lack of such knowledge leaves ample room for further research. In this case, it prompted the question: are there non-visual characteristics of landscape that symbolise the Dalmatian region and, if yes, which ones?

\section{DALMATIA AS A RESEARCH AREA}

For the research of sensory landscape identity, the Dalmatia region was chosen. It is the Mediterranean part of Croatia, situated on the central eastern Adriatic coast. It is an area with very distinctive regional identity within Croatia and, in terms of tourism, one of the most interesting and vital regions. The characteristics of Dalmatian landscape are a frequent subject 
DRUŠ. ISTRAŽ. ZAGREB GOD. 22 (2013), BR. 2, STR. 277-302

KLJENAK, M. ET AL.: EXPERIENCING... in everyday communication of its inhabitants: they comment on the weather, the heat, landscape beauty and the like. They are also often mentioned in the media, in TV or radio commercials and are common elements of Dalmatian folk and pop songs. All this creates the impression of landscape diversity of Dalmatia and a remarkable attachment of the local people to their environment through all sensory modalities. It arises from the specific geographical and climatic conditions of the locale and translates into a recognisable lifestyle, inherent, as Radica (1971) and Mišetić (1997) point out, to Dalmatians as well as to people of other Mediterranean regions, especially those living by the sea. Radica (1971, pp. 50-51) captured the essence of such living in the following words: "Sunny winter afternoons turn the entire Mediterranean coast into a great terrace, where people discuss, protest, build, and destroy, but mostly lament and complain. The sun, which kills these nations in summer, gives them strength and hope in winter".

Today, however, the name Dalmatia exists only as a historical horonym that has through a turbulent history of this area remained in the memory, consciousness, and identity of local and even wider population (Mirošević, 2011). In the modern organisation of the Republic of Croatia, Dalmatia does not exist as an administrative unit. It also cannot be isolated as a homogenous geographical region. Therefore, it was necessary to define its territory in this research. According to its most recent historical boundaries and the actual social perception, Dalmatia is here defined as a region composed of four Croatian counties in what is referred to as the Southern Croatian Littoral (see Crkvenčić et al., 1974): Zadar, Šibenik-Knin, Split-Dalmatia and Dubrovnik-Neretva County. Excluded was the northernmost part of the Zadar County - the hinterland of the Velebit Mountain; by its relief, climatic, and even cultural characteristics, it belongs to the South Lika region.

\section{METHODOLOGICAL APPROACH}

The quest for sounds, and especially smells, tactile sensations and tastes as potential characteristics of landscape identity is still a novelty in the field of landscape perception and evaluation. Thus choosing the appropriate method was a challenge. According to Zube, Sell and Taylor (1982, cited in Ndubisi, 2002), experiences of landscape are best understood through the creative work they inspire. Unlike visual perception and collective notions formed thereupon, which are primarily revealed and conveyed through visual media, the role of non-visual landscape properties in social perception was to be examined through textual forms of expression. The underlying rationale for this is the fact that the written word enables conveying visual as well as non-visual impressions. 
DRUŠ. ISTRAŽ. ZAGREB GOD. 22 (2013), BR. 2, STR. 277-302

KLJENAK, M. ET AL.: EXPERIENCING..
Written documents are an important segment of culture and inextricably connected to the space and time they were created in. As such, they are not merely a reflection of the author's attitudes, but they also depict the actual social perception of a shared landscape. The role of textual media in designing and understanding the social conception of the environment is widely recognized (see Hough, 1990; Lewis, 1979; McHarg, 1992; Meinig, 1979; Mišetić, 2004; Nogué \& Vicente, 2004; Pink, 2009; Skoko, 2004; Sopher, 1979; Tuan, 1990, 1979). "Literature is", says Tuan (1979, p. 98), "made up of words that have evocative as well as analytical power; they combine subtlety with precision." This can also be said for other textual contents and forms. They provide an insight into how people perceive their living environment, how they feel in it, which aspects of environment they value and to what extent.

According to the abovementioned, it was decided that a content analysis method be applied. The sources of analysis were two types of written artefacts wherein the Dalmatian landscape is a common theme: lyric poetry and promotional materials. The aim was to detect the words, phrases and sentences that describe sensory experiences of Dalmatia.

\section{THE METHOD: CONTENT ANALYSIS}

Although it is primarily considered as a qualitative research method, the advantage of integrating qualitative with quantitative approach to content analysis is often emphasized (see e.g. Halmi, 1996; Mišetić, 2004; Tkalac Verčič, Sinčić Ćorić, \& Pološki Vokić, 2011). In this research, the qualitative aspect of the method focuses on the identification of spatial characteristics that shape the social perception of Dalmatia and act as landscape symbols of the region. The main goal was, however, the quantitative measurement: the ratio between perceptual modalities in experiencing and presenting Dalmatia. Another goal was to examine the proportion between various characteristics (or types of characteristics) structuring the visual, auditory, olfactory, tactile and gustatory perception of Dalmatia.

\section{Samples and units of analysis}

According to Halmi (1996), the comprehensiveness of empirical material is a common problem in sampling various symbolic contents. Due to the nature of the content, the overall number of potential units of analysis (in this case all poems or promotional materials) is unknown. This prevents random sampling and, consequently, representativeness. Nevertheless, when a relatively undefined phenomenon wants to be explored and explained, it is useful, point out Tkalac Verčič et al. 
DRUŠ. ISTRAŽ. ZAGREB GOD. 22 (2013), BR. 2 STR. 277-302

KLJENAK, M. ET AL EXPERIENCING...
(2011), to apply purposive sampling consistent with the research criteria and researcher's estimation. The advantage of this, they argue, is the selection of those units of analysis that are believed to contribute most to the explanation of the research question. As a form of purposive sampling, the sample of units according to an appropriate criterion was compounded for each content group (see Tkalac Verčič et al., 2011).

One analysed group is lyric poetry contextually related to Dalmatia. Being relatively short, lyric poem was considered convenient for the analysis; unlike some other literary forms, it enables reviewing a larger number of units in less time. Lyric poetry, especially one regarding homeland, frequently reflects the author's intense attachment to the country he/she was born in, has lived or still lives in. It is expressed through descriptions of the region and an emotional tonality of the poem. Landscape - as the main theme - was not a necessary condition. Poems of different thematic profiles were analysed (e.g. love or social poems), assuming that at least one specific sensory experience of the Dalmatian region or landscape occurs in them. Following that criterion, among a large number of poems, 510 were selected and analysed. The sample comprised materials available in the City Library and Research Library in Zadar and to a lesser extent from private collections and the Internet. The unit of analysis in this group was one poem. A few haiku poetry collections were included, where every poem does not have its own title, thus a group of haiku poems under the same title was considered as the unit of analysis.

Promotional materials, predominantly those tourism-related, and several commercial ones (promoting products and services) are the other analysed group. This category included printed materials (e.g. brochures, flyers, tourist guides) and content published on the Internet. The latter mostly comprised webpages advertising private accommodation (apartments) and the official websites of Tourist Boards. The selection criterion was that the content of the unit presented the Dalmatian area, service or a product. The unit of analysis was one advertising entity, regardless of its size: one brochure, flyer, guide or a website. For the analysis of private accommodation advertising, the unit of analysis was only a webpage (usually Home page) on which a welcome text is given. Its purpose is to describe the atmosphere of the immediate site and the advantages it provides for the vacation. Other pages on these websites, describing the entire locality or a region, were not analysed, in order to avoid repetition, which has already been described in the official promotional materials. In this group, a total of 765 units were included. 


\section{Categories for content classification}

Before the implementation of analysis procedure, a smaller number of units were reviewed and two levels of categories for the classification of text were defined: (1) main categories and (2) subcategories (Figure 1). Six main categories designate perceptual modalities: V-visual, A-auditory, O-olfactory, etc. Twenty seven subcategories denote a specific feature or a type of features within a modality (e.g. subcategory $V(s e a)$ contains visual experiences of the sea, such as blue, stormy or moonlit sea). A table for data input was created accordingly (Figure 2). To simplify the table, every category and subcategory was appropriately abbreviated.

2 FIGURE

Categories for content classification
(1) FIGURE 2

Segment of the table for data input

\begin{tabular}{|c|c|c|c|}
\hline 1 & Visual & 4 & Tactile \\
\hline $\mathrm{V}(\mathrm{l})$ & V(natural and cultural landscape) & $\mathrm{T}(\mathrm{a})$ & $\mathrm{T}$ (air) \\
\hline $\mathrm{V}(\mathrm{s})$ & $\mathrm{V}(\mathrm{sea})$ & $\mathrm{T}(\mathrm{s})$ & $\mathrm{T}($ sea $)$ \\
\hline $\mathrm{V}(\mathrm{ar})$ & V(architecture) & $\mathrm{T}(\mathrm{w})$ & $\mathrm{T}$ (wind) \\
\hline$V(b)$ & V(boats and ports) & $\mathrm{T}(\mathrm{cl})$ & $\mathrm{T}$ (climate) \\
\hline $\mathrm{V}(\mathrm{sd})$ & V(specific details) & $\mathrm{T}(\mathrm{o})$ & $\mathrm{T}$ (other) \\
\hline 2 & Auditory & 5 & Gustatory \\
\hline $\mathrm{A}(\mathrm{s})$ & $\mathrm{A}($ sea $)$ & $\mathrm{G}(\mathrm{f})$ & G(food) \\
\hline $\mathrm{A}(\mathrm{cc})$ & A(cicada and crickets) & $\mathrm{G}(\mathrm{oo})$ & G(olive oil) \\
\hline$A(s g)$ & $\mathrm{A}$ (seagulls) & $\mathrm{G}(\mathrm{b})$ & G(beverages) \\
\hline $\mathrm{A}(\mathrm{m})$ & $\mathrm{A}$ (music) & $\mathrm{G}(\mathrm{l})$ & G(landscape) \\
\hline $\mathrm{A}(\mathrm{o})$ & A(other) & & \\
\hline 3 & Olflactory & 6 & Compound \\
\hline $\mathrm{O}(\mathrm{ap})$ & $\mathrm{O}$ (aromatic plants) & $\mathrm{C}(\mathrm{ls})$ & C(lifestyle) \\
\hline $\mathrm{O}(\mathrm{c})$ & $\mathrm{O}$ (conifers) & C(la) & C(landscape \\
\hline $\mathrm{O}(\mathrm{s})$ & $\mathrm{O}(\mathrm{sea})$ & & atmosphere) \\
\hline $\mathrm{O}(\mathrm{f})$ & $\mathrm{O}$ (food) & $\mathrm{C}(\mathrm{o})$ & $\mathrm{C}$ (other) \\
\hline $\mathrm{O}(\mathrm{o})$ & O(other) & & \\
\hline
\end{tabular}

Perceptual modality / Specific landscape feature(s)

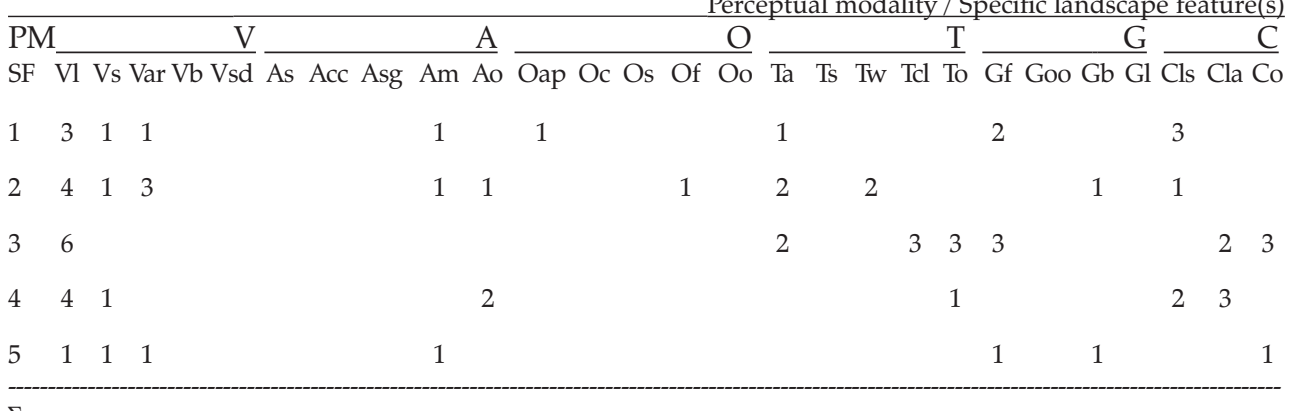

$\Sigma$

PM - Perceptual modality; SF - Specific feature (subcategory); First-column number (1, 2, 3...) - ordinal number of the analysed unit; $\Sigma-$ The sum of characteristics within a subcategory or modality 
DRUŠ. ISTRAŽ. ZAGREB GOD. 22 (2013), BR. 2 STR. $277-302$

KLJENAK, M. ET AL. EXPERIENCING...
Compound perception refers to descriptions of those experiences which comprise two or more modally different sensations (e.g. sight and sound, sound and smell). Three subcategories are distinguished therein: lifestyle depicts the atmosphere of towns and villages through various events, customs and everyday activities; landscape atmosphere outlines the ambiance of natural and rural sites, implying sensory-emotional experiences like 'peacefulness'; subcategory other refers to commonly multi-modally experienced landscape characteristics like 'pebbly' (visual, tactile, auditory).

\section{Recording unit and enumeration criterion}

Within the unit of analysis, a recording unit is a word, phrase or a sentence describing one characteristic experience of Dalmatian landscape (e.g. blue sea, scent of immortelle, heat). The enumeration of recording units is based on registering the presence or the absence of abovementioned descriptions, regardless of the number of their potential repetitions in the analysed unit. The sum of characteristics in a subcategory may indicate their diversity and frequency through the sample. However, it does not illustrate the intensity of experiences. In other words, it shows which properties of landscape are most often used to describe Dalmatia, but not which of them were most intensively experienced.

\section{Analysis procedure and data processing}

Data entering was conducted manually, the main reason being the nature of the content. Sensory impressions and experiences of landscape are not always explicitly expressed, but can be implied. Therefore, understanding and correct classification of the text depend often on the context.

Since this is the first comprehensive study of sensory landscape properties in Croatia (and probably beyond), only the basic statistical calculations were implemented. The aim was to present to what extent non-visual landscape features constitute the collective perception of the region and to detect the most prominent ones.

\section{RESULTS}

The analysis has shown that Dalmatian landscape is, in the reviewed material, experienced and presented through characteristics from all five perceptual modalities. The majority of experiences arise from visual perception. Respecting the fact that an average person receives most environmental information via sight, it is understandable. However, other sensory properties constitute the perception of Dalmatia to a reasonable degree. In both content groups - poetry and promotion- 
DRUŠ. ISTRAŽ. ZAGREB GOD. 22 (2013), BR. 2, STR. 277-302

KLJENAK, M. ET AL.: EXPERIENCING...

F FIGURE 3

Shares of perceptual modalities in des-

criptions of Dalmatian landscape

(1) FIGURE 4

Largest subcategories

in poetry

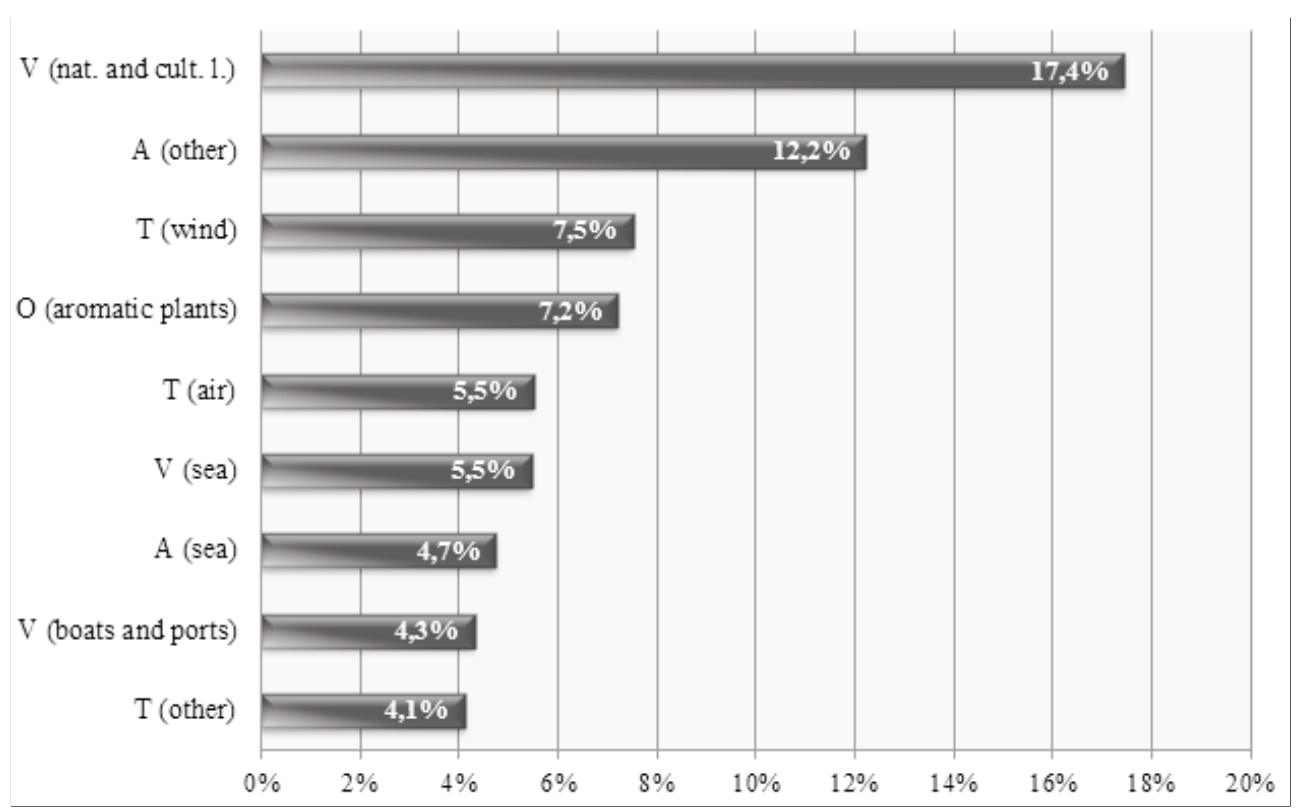

al materials - visual characteristics comprise about $30 \%$ of the overall experience. The share of other modalities varies and, noticeably, with regard to the content's purpose (Figure 3).

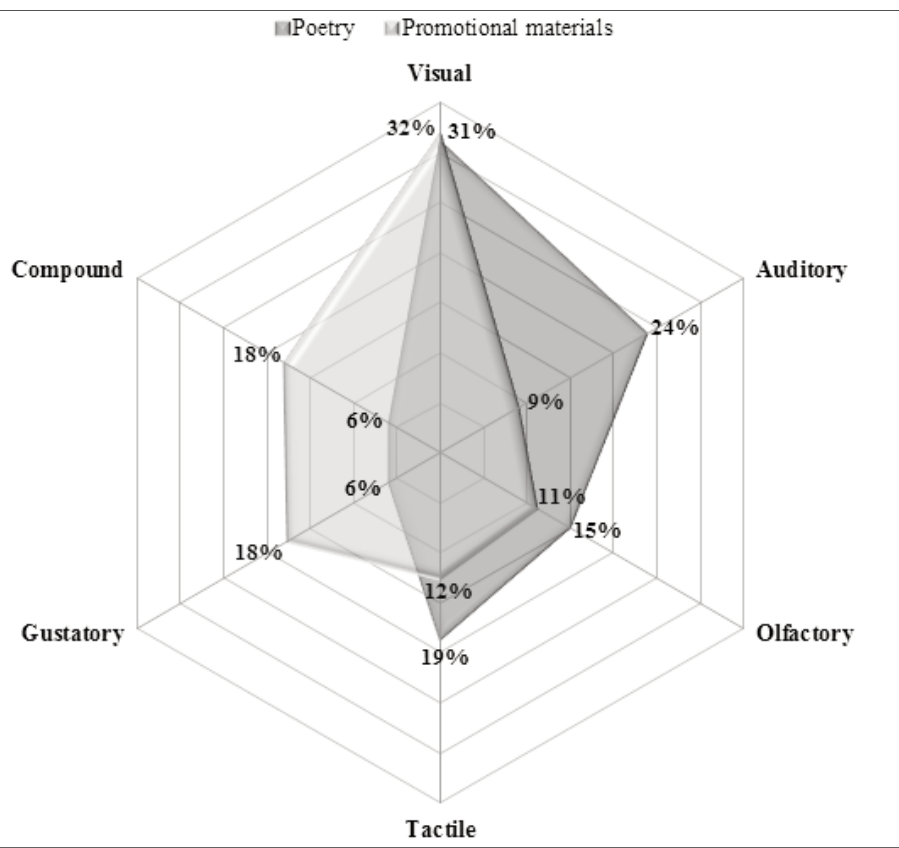

The nine most numerous types of characteristics (i.e. subcategories), having a share of equal to or greater than $4 \%$ in the corresponding sample, can be isolated in each content group. For each group, it is a different set of subcategories (Figures 4 and 5). 
DRUŠ. ISTRAŽ. ZAGREB GOD. 22 (2013), BR. 2 STR. 277-302

KLJENAK, M. ET AL: EXPERIENCING...

(1) FIGURE 5

Largest subcategories in promotional materials
In lyric poetry, ephemeral experiences like tactile sensations of the wind, scents of herbs and sounds of the sea compose the experiential structure more than in promotional materials. Here, the expectedly largest subcategory of visual characteristics is followed by four different non-visual subcategories. Lyric poetry is characterised by its profound sense for landscape, arising mostly from the poets' strong attachment to the landscape they describe. Such intimate understanding of landscape character translates into textual descriptions of the sights, sounds, scents and all other features and their nuances well familiar to the author.

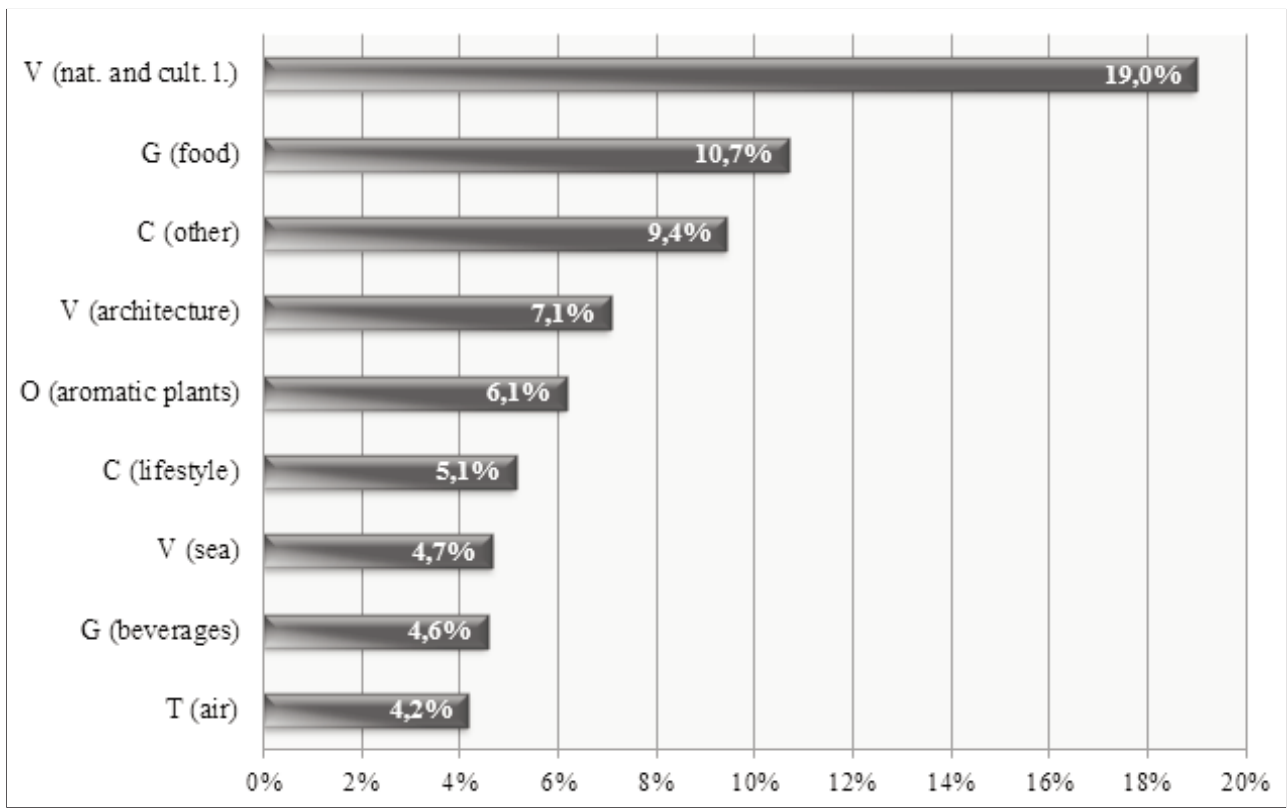

In promotional materials, on the other hand, the landscape features on which tourism promotion is usually based are predominant. Beside the visual characteristics of Dalmatia, the emphasis is largely on gastronomic specialties - G(food), G(beverages); environmental qualities such as clean sea, fresh air and pebble beaches - C(other); sojourns in traditional urban and rural surroundings and visiting cultural sites - V(architecture); and everyday activities, various events and customs - C(lifestyle).

Another indicator of how much a subcategory contributes to the regional distinctiveness is the number of units of analysis in which at least one of its representatives occurred. This displays its distribution within the sample and a certain continuity of the characteristics it represents. For example, in 308 out of 510 analysed poems at least one landscape characteristic was registered in subcategory V(natural and cultural landscape). In the remaining 202 poems there were no characteristics registered in this subcategory. 


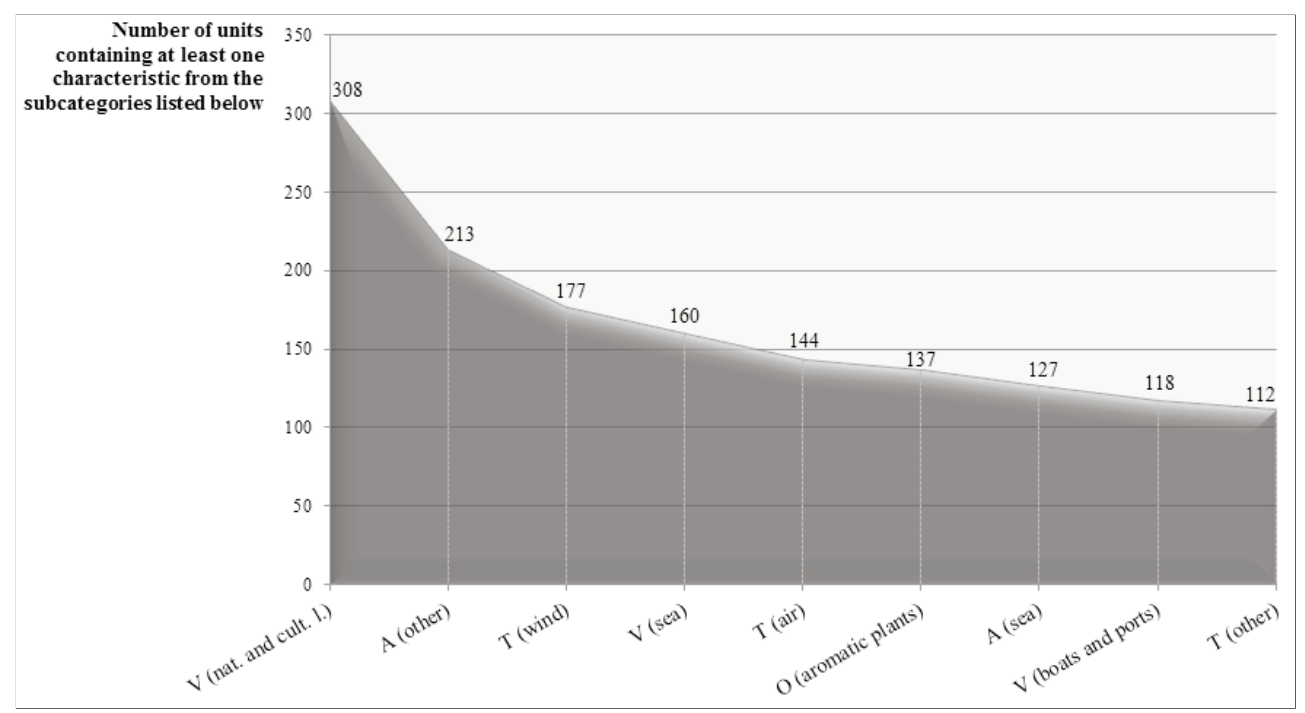

(1) FIGURE 6

Sample "Poetry": Subcategories (characteristics) mentioned in over $20 \%$ of poems
Comparison of Figures 4 and 6 manifests that, beside a minor difference in their sequence, the same subcategories prevail in both illustrations. This further confirms their significance in the perception of Dalmatia. Promotional materials show a somewhat greater sequence change (although the differences are numerically minor), but, here too, mostly the same subcategories occur (Figure 7).

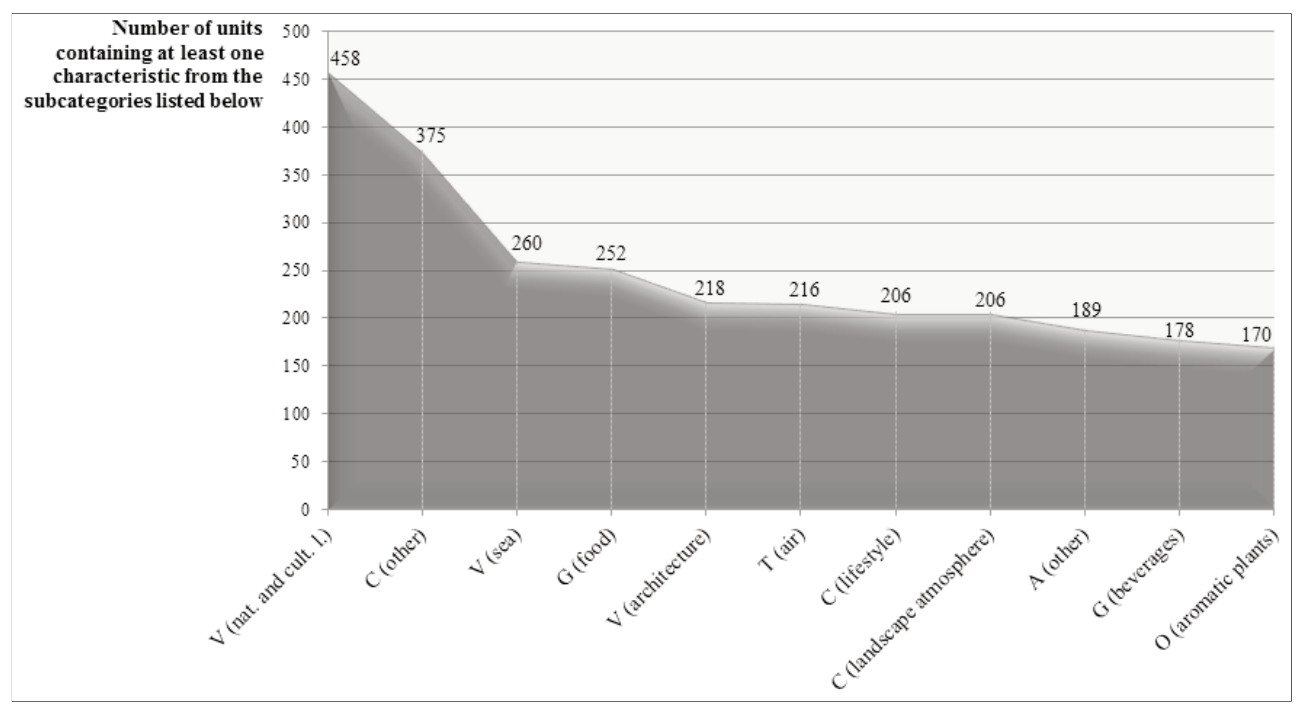

ก FIGURE 7

Sample "Promotional materials": Subcategories (characteristics) mentioned in over $20 \%$ of all units
In short, in both content groups, the most numerous subcategories are, in a slightly different order, also the ones with the greatest distribution. Hence, both from the standpoint of quantity and distribution, the perception and presentation of Dalmatia are based on an approximately equal set of characteristics in corresponding samples. 
DRUŠ. ISTRAŽ. ZAGREB GOD. 22 (2013), BR. 2 STR. $277-302$

KLJENAK, M. ET AL: EXPERIENCING...
The landscape of Dalmatia is perceived through all the proposed perceptual modalities and within each there are characteristics that act as symbols of the region. Some of them are more pronounced in poetry and others in promotional materials. Thus, particular symbols should be identified through a comparative analysis rather than by merging the samples. The following results show which properties structure the experiential map of a particular sensory component of Dalmatian landscape. Qualitative analysis has uncovered some interesting, most usual or rare and extinct experiences typical of Dalmatia.

\section{Visual identity of Dalmatia}

In the visual experience of Dalmatia, the characteristics of subcategory V(natural and cultural landscape) (Figure 8), as expected, have the greatest share. This subcategory is particularly diverse and includes a wide range of landscape features

(1) FIGURE 8

Visual characteristics (subcategories) ratio in the overall visual experience of Dalmatia and qualities - from a single plant (e.g. blossoming broom) to general landscape characteristics like beautiful bays and islets, deep river gorges or rough karst. The characteristics registered here could be further divided into several subcategories.

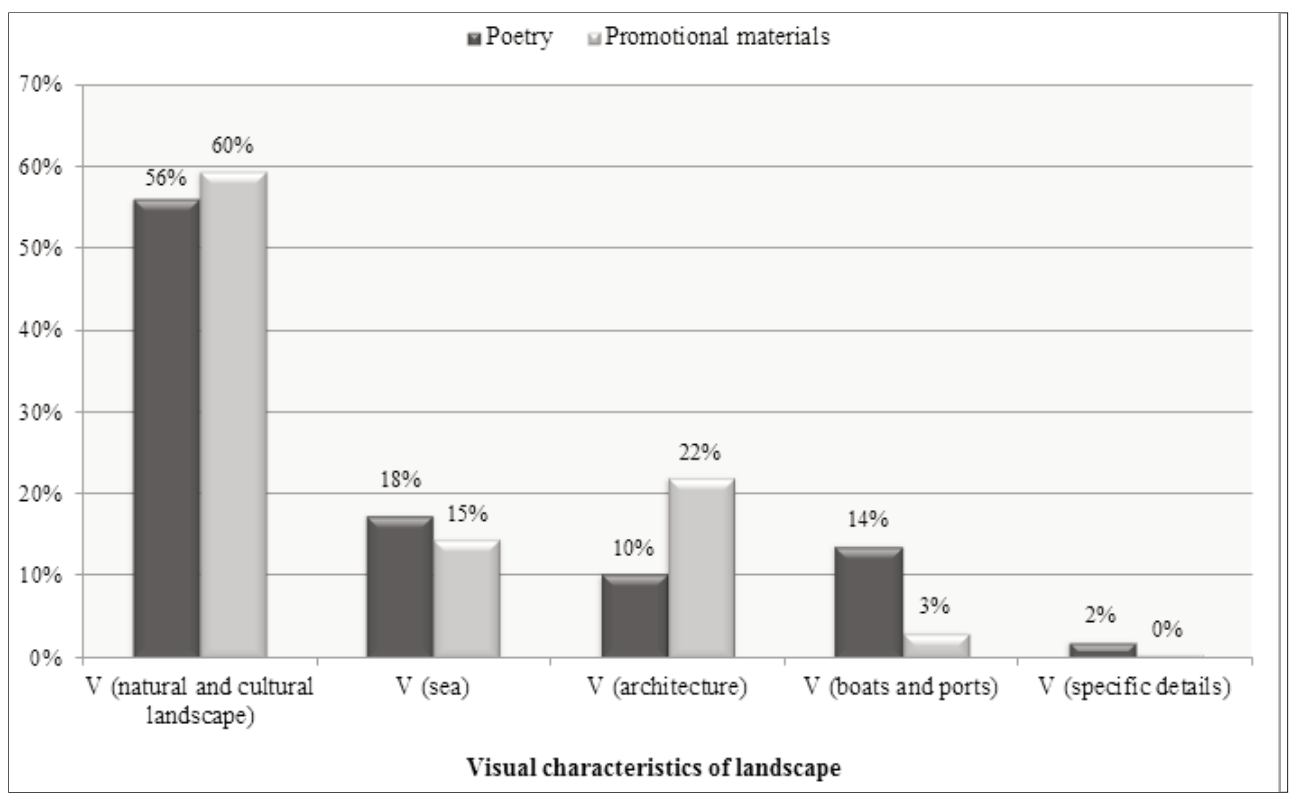

Being very frequent, the elements of cultural landscape (vineyards, olive orchards, dry stone walls, etc.) could form an individual subcategory. This is also true for general landscape characteristics. Mediterranean vegetation, with descriptions of characteristic plants and general lushness, is another large group of motifs. Such additional division would probably result in more moderate differences between subcategories. 
DRUŠ. ISTRAŽ. ZAGREB GOD. 22 (2013), BR. 2, STR. 277-302

KLJENAK, M. ET AL.: EXPERIENCING..
Images of the sea, with at least $15 \%$ in both samples, can be considered a significant visual characteristic of Dalmatia; especially considering the relatively small variability within the subcategory $V($ sea) (i.e. it consists of only a few typical maritime scenes). Promotional materials indicate that traditional architecture (stone houses, streets and squares, churches and fortifications) is another symbol of the region. The analysis of poetry has revealed that images of boats, harbours and ports (another subcategory with low variability of motifs) are also characteristic elements in the perception of Dalmatia.

\section{Auditory identity of Dalmatia}

(1) FIGURE 9

Auditory subcategories ratio in the overall

auditory experience of Dalmatia

Auditory perception of the Dalmatian landscape has proven to be more complex than it was originally thought. This clearly illustrates the subcategory $A$ (other), which includes the majority of all registered descriptions of auditory experience (Figure 9). Beside the first four subcategories, auditory composition of the region is undoubtedly formed by many other sounds.

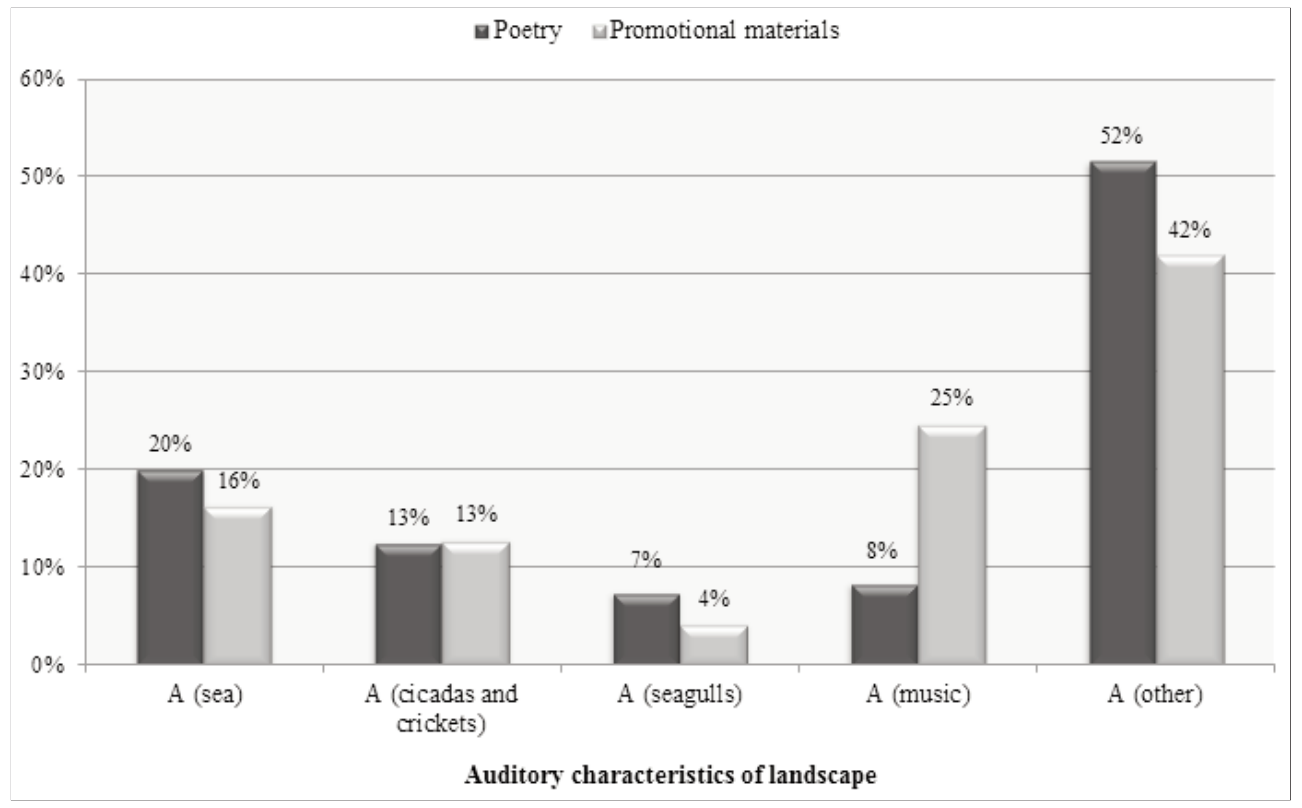

Qualitative review suggested that several individual subcategories could be derived from $A$ (other). Wind related sounds are relatively frequent, as well as sounds of boats and ships (engines, whistles, masts, ropes). Sounds of birds, insects and other animals could also be classified into a separate subcategory. Another specific group are human sounds like murmur (e.g. at markets, fish markets, squares, streets, and beaches), small talk, local dialects and foreign languages. 
DRUŠ. ISTRAŽ. ZAGREB GOD. 22 (2013), BR. 2 STR. 277-302

KLJENAK, M. ET AL. EXPERIENCING...
In the map of auditory perception, sounds of the sea represent an important feature of auditory landscape, with shares of $20 \%$ and $16 \%$. Chirping of cicadas (during the day) and crickets (at night) participates with 13\%. Considering that this subcategory consists only of two specific sounds and that they occur exclusively in the summer, these are also a significant feature of auditory perception and regional distinctiveness.

What is surprising is that the seagull's cry is rarely mentioned in both samples. Dalmatia being a coastal region, they were expected to be more common. In some future analysis they could be grouped with sounds of other birds (swifts, swallows, blackbirds), which are frequently found in the subcategory A(other).

Furthermore, promotional materials indicate that Dalmatian music - with traditional a capella (klapa) songs, pop songs and sounds of mandolin and guitar - is an integral component of auditory experience. Although in poetry music participates with only $8 \%$ in the overall auditory perception, it contains the same abovementioned characteristics, which confirms them as regional symbols.

\section{Olfactory identity of Dalmatia}

(1) FIGURE 10

Olfactory subcategories ratio in the overall olfactory experience of Dalmatia
Olfactory experience of Dalmatia is primarily based on the scents of aromatic herbs; mostly rosemary, immortelle, lavender, sage, heather, myrtle, and other (Figure 10). They are a distinctive olfactory symbol of the region.

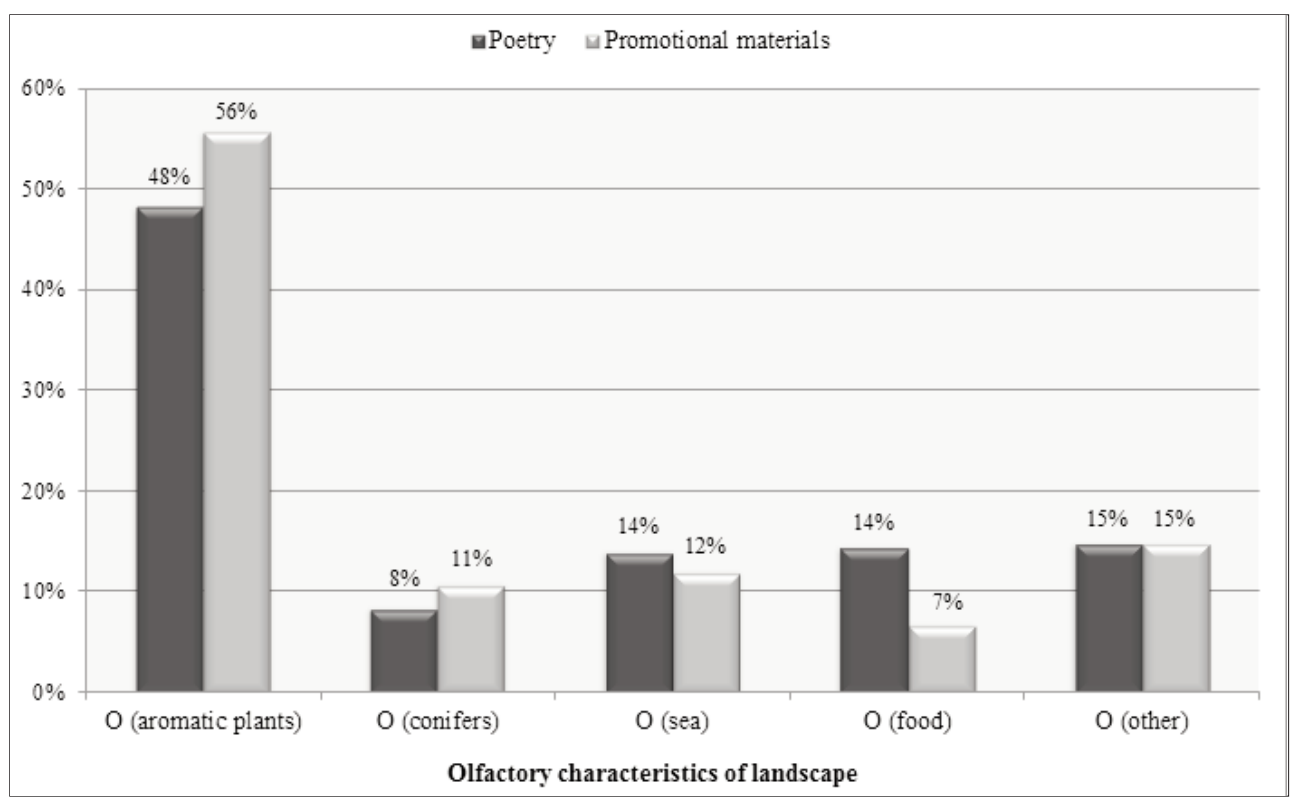

Other olfactory characteristics (subcategories) have a smaller but relatively evenly represented share in the olfactory 
DRUŠ. ISTRAŽ. ZAGREB GOD. 22 (2013), BR. 2, STR. 277-302

KLJENAK, M. ET AL.: EXPERIENCING..

category itself and in the overall samples. None of these subcategories can be discerned as a prominent symbol of olfactory identity, which was particularly unexpected regarding the scents of conifers (pine trees and cypress) and sea.

However, uniformity among subcategories indicates olfactory diversity of the Dalmatian landscape. This is additionally confirmed through numerous odours recorded in the subcategory $O($ other $)$ - the smell of earth, rain, wind, spring, ships, oil in harbours, etc.

\section{Tactile identity of Dalmatia}

Tactile perception of Dalmatia is dominated by three types of experiences: air properties, prevailing winds and the feeling of texture and temperature of surfaces and objects - T(other)

(1) FIGURE 11

Tactile subcategories ratio in the overall

tactile experience of Dalmatia
(Figure 11). Due to a mild climate, considerable time is spent outdoors, wherefore the air qualities and their changes are commonly perceived. In both samples, Dalmatia is recognized for its warmth, sultriness, and fresh air at night.

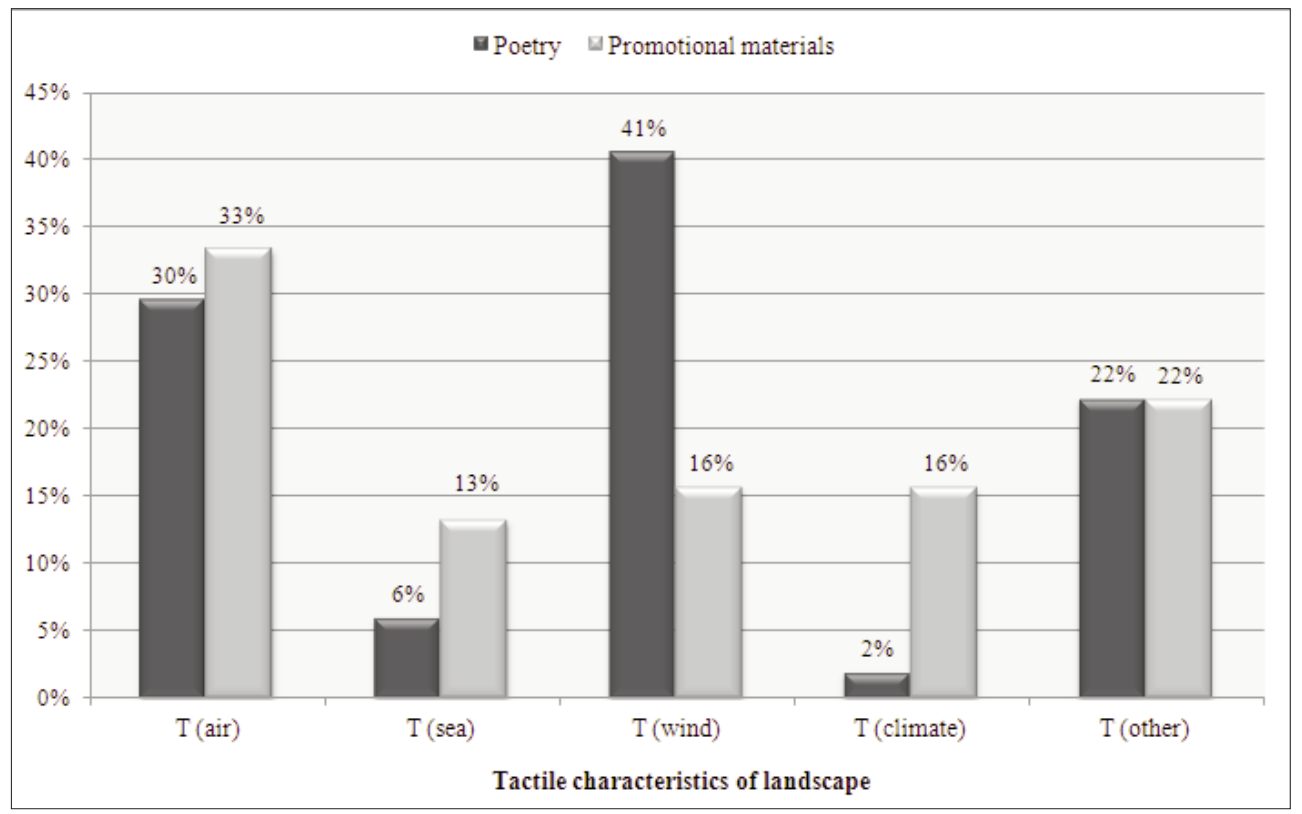

The most prominent tactile experiences found in poetry are those generated by the prevailing winds (bora, sirocco and maestral). They greatly affect everyday life of the local people, in a functional, perceptual and emotional sense, and as such, symbolize the region. Remarkably less are they mentioned in promotional materials, where tactile presentation of Dalmatia relies more evenly on descriptions of the warm sea $(13 \%)$, the wind (mostly maestral, 16\%) and mild climate in general, $16 \%$. 
DRUŠ. ISTRAŽ. ZAGREB GOD. 22 (2013), BR. 2 STR. 277-302

KLJENAK, M. ET AL: EXPERIENCING...
Subcategory T(other) includes some very interesting experiences of the environment, one of the most common being the experience of shade in the summer. The feeling of surface texture and warmth has a noticeable share as well (e.g. warm stone, sharp rocks, smooth flagstones used for paving streets, hot or wet sand, smooth pebbles, touch of dry grass, thornbushes or pine needles). These tactile sensations could form a separate subcategory in future analyses.

As a source of tactile experience, the sea does not have a great symbolic value.

The subcategory climate comprises general climatic characteristics of the region: the warm south, the warm Mediterranean, mild winters, summer droughts, etc. Dalmatia is, thus, primarily perceived as a warm and sometimes arid area. Since the descriptions of climate, as well as those of shade, mostly relate to the perception of air temperature, in future analyses it would be sensible to include these into the subcategory T(air).

\section{Gustatory identity of Dalmatia}

There are two very typical gustatory characteristics of Dalmatia. The first one is local foodstuffs and traditional dishes (e.g. fish, seafood, fresh vegetables, lamb, grilled dishes, desserts, and products like cheese, smoked ham and honey). Olive oil does not have a role of a gustatory symbol by itself, but it contributes considerably to the local gastronomy. Gastronomic offer is an important aspect of promotion of the region.

(1) FIGURE 12

Gustatory subcategories ratio in the overall gustatory experience of Dalmatia
The other distinctive gustatory characteristic of Dalmatia is beverages; these mostly refer to wine from indigenous varieties, prosecco, and herb and fruit flavoured brandies (Figure 12). Therefore, Dalmatian cuisine is strongly associated with the landscape and the lifestyle within which it has evolved.

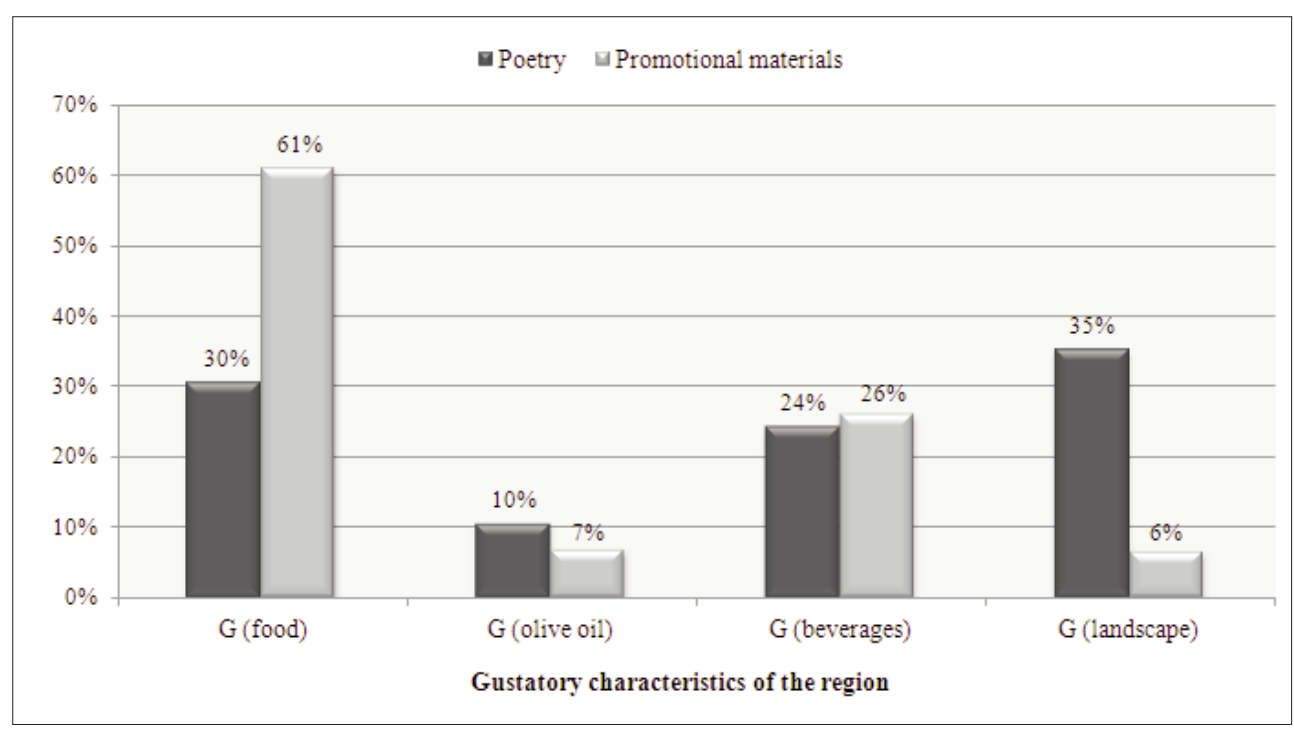


DRUŠ. ISTRAŽ. ZAGREB GOD. 22 (2013), BR. 2, STR. 277-302

KLJENAK, M. ET AL.: EXPERIENCING..

Although in poetry the gustatory perception is represented with only $6 \%$ in the overall experience, it is interesting that it mostly relies on the immediate tastes of the landscape. The understanding of subtle landscape nuances, inherent to lyric poems, reveals that the most impressive among the tastes of landscape are saltiness and the tastes of herbs and fruits accessible directly in the surroundings (e.g. sweet fruits of fig, mulberry and grape, sweet and sour rosehip, carob, the astringency of myrtle and heather). Dalmatian landscape is, therefore, perceived also via sense of taste. A good example of integrating gustatory characteristics in tourism promotion is the popular video of the Croatian National Tourist Board entitled When heart says summer, it says Croatia: "...it says green, sweet, salty..." (HRCroatia, 2009).

\section{Characteristic compound experiences of Dalmatia}

(1) FIGURE 13

Compound

subcategories ratio in

the overall compound

experience of

Dalmatia
This category includes multisensory experiences - those that are perceptually not clearly defined but imply a combination of various stimuli. Compound perception captures the typical atmosphere of the region - aspects upon which the spirit of place is built (Figure 13).

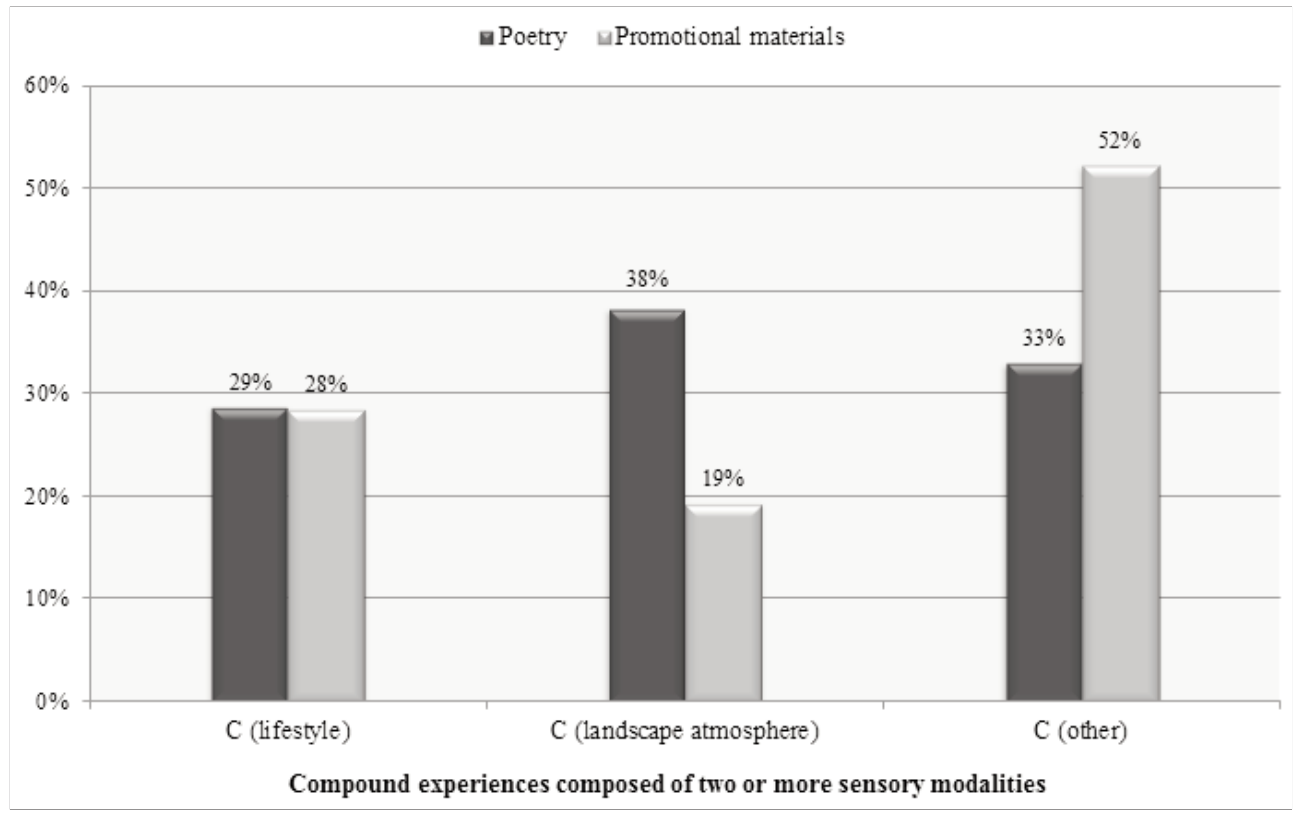

The analysis has shown that Dalmatian genius loci is perceived through two typical aspects. Firstly lifestyle, characterised by a relaxed and slower pace of life, outdoor gatherings, a vivacity of towns, daily activities and rituals, customs, summer events, etc. Mediterranean lifestyle, with warm climate and beautiful weather allowing frequent outdoor stays during all seasons, is typical of Dalmatia. However, several poetry 
DRUŠ. ISTRAŽ. ZAGREB GOD. 22 (2013), BR. 2, STR. 277-302

KLJENAK, M. ET AL.: EXPERIENCING...

\section{DISCUSSION}

examples show the contrast of the vibrant summer atmosphere to a winter desolation and loneliness. Though the effect of an increasingly hectic lifestyle can also be felt in Dalmatian towns, the mentioned Mediterranean pace still persists noticeably.

The other aspect refers to the atmosphere of rural and natural areas, the experience of which involves aesthetic and emotional dimensions: tranquillity, calm sea, gentleness, pleasant idleness (siesta or Dalmatian fjaka), calm before the storm, etc.

Subcategory C(other) includes landscape properties in which various modalities are combined into a single experience. Attributes pebbly or sandy beach, for instance, comprise visual and tactile sensations; lavender fields imply visual and olfactory sensations. Other frequently mentioned are clean sea (visual, olfactory), fresh air (olfactory, tactile), bumblebees around lavender (visual, auditory, olfactory), low tide (visual, auditory, olfactory), cold freshwater springs (gustatory, tactile), etc. Multisensory experiences constitute nearly a fifth of the descriptions in promotional materials, whereas $52 \%$ refers to subcategory $C$ (other). This further underpins the assumption about the significance of non-visual experiences in the perception of Dalmatia.

Characteristics of this category demonstrate that human experience of place is not a mere aggregate of sensations of various modalities. Rather, the notion of place results from a dynamic interaction of unique sensations and feelings emerging from direct communication with the environment.

Since poetry and promotional materials are two different forms of written communication, it was reasonable to expect that the results would also somewhat differ. However, non-visual landscape features constitute a considerable part in both. The revealed distinctions have arisen from the differences in type and purpose of the content(s). Dual analysis has proven to be extremely useful, for each uncovers different characteristics of the sensory landscape identity of Dalmatia. In lyric poetry, landscape is regarded from the perspective of everyday coexistence and constant immediate interaction with it. It is described in the light of all seasons. It is understood, reflected upon and felt rather profoundly. All this reflects in a remarkable share of auditory, olfactory and tactile characteristics.

Promotional materials, on the other hand, aim at emphasizing precisely those landscape characteristics that would contribute to the prosperity of tourism and the associated activities. Thereby, Dalmatia is mostly presented through the prism of summer. In addition to visual, gustatory characteristics are largely mentioned here (foodstuffs, traditional dishes, 
(1) FIGURE 14

Symbols of sensory landscape identity of Dalmatia (poetry)

(1) FIGURE 15 Symbols of sensory landscape identity of

Dalmatia (promotional materials) desserts, beverages, etc.). Auditory, olfactory and tactile characteristics are less frequent than in poetry. However, these ephemeral sensations are integrated into multisensory experiences contained in the category Compound, which, in this sample, has a significant share of $18 \%$. This also confirms a repeatedly emphasized interaction and synergy of senses (e.g. Gibson, 1986; Rodaway, 1994).

Figures 14 and 15 illustrate Dalmatian identity through the typical exemplars of the most prominent subcategories in corresponding samples (font size and shade indicate the characteristic's intensity in the identity structure).

\title{
cold northeasterly wind Bora, sea breeze
}

warmth of the sun, heat

\section{vineyards, olive groves Mediterranean vegetation dry walls}

\author{
sound of the sea \\ sounds of boats \\ sounds of birds and other animals \\ quietness \\ sound of the wind
}

scents of immortelle, sage and lavender

scents of immortelle, sage and lavender

warm climate, the sun

indigenous wines

sea food, smoked ham and cheese

stone houses, streets and squares

blue sea Mediterranean vegetation
dry walls vineyards, olive groves

clean sea, shingle beaches and fresh air vivacity of towns and relaxed lifestyle

sound of the sea sounds of birds and other animals sound of the wind sounds of people quietness

Though, respecting the aforesaid, it is more reasonable to regard the two analysed groups separately, when observed as a whole, it is clear that, aside from the expectedly greater 
DRUŠ. ISTRAŽ. ZAGREB GOD. 22 (2013), BR. 2 STR. 277-302

KLJENAK, M. ET AL. EXPERIENCING... share of the visual, non-visual modalities are rather evenly represented in the perception of Dalmatia.

The analysis has corroborated some already recognised elements of Dalmatian landscape identity. In terms of the visual, these are certainly the elements of non-built cultural landscape (vineyards, olive orchards, dry walls, etc.), such as $\mathrm{Hr}$ dalo, Aničić, Pereković, Rechner, and Andlar (2008) and Butula et al. (2009) mentioned in their studies. As an auditory symbol, klapa singing can be distinguished. According to Povrzanović (1991) it is a unique element of Dalmatian cultural identity. Moreover, it is at the same time an auditory feature of landscape identity, not only due to its semiological association to the actual regional territory, but because it is often sung and heard outdoors, complementing, thus, Dalmatian atmosphere.

\section{CONCLUSION}

Based upon the results, it can be deduced that all the considered sensory dimensions participate in the Dalmatian landscape identity. Within each modality, it is possible to distinguish one or more characteristics (or group of characteristics) that carry a strong symbolism of the region. Respecting that the interaction with the environment assumes an active involvement of all senses, consequently, the attachment to and identification with the landscape are built upon each of them. Local people recognize, evaluate and are strongly related to many non-visual landscape features. Landscape perception is a multisensory composition of sights, sounds, smells, tactile sensations, tastes and unique ambiences. Hence, landscape (and places in general) can be said to have a complete sensory rather than just visual identity.

By knowing the characteristics of sensory landscape identity, we understand the values of our society, our culture. It is important for preserving all that by which a place, a community, a region is recognizable, different and interesting. Identifying the typical auditory, olfactory, tactile and gustatory landscape characteristics should contribute to a better articulation of the region's character in tourism as well as in the production and promotion of authentic products and services. More importantly, it may indicate the necessity to preserve and protect certain elements of natural and cultural heritage that generate such characteristics (e.g. to protect plant species whose scents are recognised as an olfactory identity). The knowledge of sensory landscape properties may also be applied in landscape design. An excellent example is the sea organ in Zadar, whose sound is based on five tones derived 
DRUŠ. ISTRAŽ. ZAGREB GOD. 22 (2013), BR. 2, STR. 277-302

KLJENAK, M. ET AL. EXPERIENCING..

\section{NOTES}

\section{REFERENCES}

from the matrix of Dalmatian klapa singing (Zadar County Tourist Board, 2009). Dominant and less recognised plant fragrances could also be more thoroughly explored and thus integrated in the concepts of tourism promotion, authentic products development and landscape design. Furthermore, a great potential of non-visual characteristics lies in various forms of health tourism - climatotherapy, thalassotherapy, balneotherapy. There are currently only a few centres of health tourism in entire Dalmatia; in Nin, Biograd, Makarska and Vela Luka (Ivanišević, 2002).

This study represents only the initial research on sensory landscape characteristics and the symbolism ascribed to them. In order to acquire more profound understanding of the distinctive non-visual features of Dalmatia, further analyses should focus on a thorough examination of landscape characteristics, values and experiences within an individual perceptual modality. Thereby, from subcategories such as $V(n a-$ tural and cultural landscape) and A(other), which have proven to be markedly diverse, additional subcategories might be derived and considered separately as landscape symbols. A deeper insight in the actual notion of the researched question of various social groups might be obtained by questionnaire. Also, some field methods could be applied to detect, record and even map the non-visual landscape properties.

This research represents a step towards a better understanding of the aspects that shape the physical and emotional experience of landscape, determining thus our attitudes, choices and behaviour. Ultimately, it complies with the sustainability concept; firstly, with respect to the potential protection of various sensory values of a landscape, but equally as a possibility of their utilisation for the benefit of humans.

1 The term non-visual is used here in order to differentiate between visual and the other four sensory modalities, without having to mention them individually each time.

2 The project was founded by the Grup PaisatgesonorUB within the Department of Sculpture at the University of Barcelona, School of Fine Arts and supported by the Landscape Observatory of Catalonia.

Anzani, G. (2010). Sound perception and landscape identity. In Conference materials (Vol. 2. Short Communications). Presented at the Living Landscape - The European Landscape Convention in research perspective, Florence, Italy: Bandecchi \& Vivaldi Editori. Available at http://www.academia.edu/2281103/Sound_perception_and_landsca pe_identity 
DRUŠ. ISTRAŽ. ZAGREB GOD. 22 (2013), BR. 2 STR. 277-302

KLJENAK, M. ET AL.: EXPERIENCING...
Borthwick, F. (2000). Olfaction and taste: Invasive odours and disappearing objects. The Australian Journal of Anthropology, 11(3), 127-140. http://dx.doi.org/10.1111/j.1835-9310.2000.tb00052.x

Butula, S., Andlar, G., Hrdalo, I., Hudoklin, J., Kušan, T., Kušan, V., \& Steko, V. (2009). Inventarizacija, vrednovanje i planiranje obalnih krajobraza Dalmacije: Područje Stona i Janjine s Malostonskim zaljevom (Inventarisation, evaluation and planning of Dalmatia's coastal landscape: Ston, Janjina and Mali Ston bay). UNDP. Available at http://www.undp.hr/ upload/file/227/113867/FILENAME/INVENT_7_S_.pdf

Casey, E. S. (1993). Getting back into place: Toward a renewed understanding of the place-world. Bloomington and Indianapolis: Indiana University Press.

Classen, C. (1990). The taste of ethnographic things: The senses in anthropology. American Ethnologist, 17(4), 800-800. http://dx.doi.org/ 10.1525/ae.1990.17.4.02a00130

Classen, C. (1997). Foundations for an anthropology of the senses. International Social Science Journal, 49(153), 401-412. http://dx.doi. org/10.1111/j.1468-2451.1997.tb00032.x

Counihan, C. (1999). The anthropology of food and body: Gender, meaning, and power. New York; London: Routledge. Available at http:// books.google.hr/books/about/The_Anthropology_of_Food_and_Bo dy.html?id=f3UKRcaDifQC\&redir_esc $=y$

Crkvenčić, I., Derado, K., Friganović, M., Kalođera, A., Mirković, D., Radica, T., \& Śegota, T. (1974). Južno Hrvatsko primorje (Southern Croatian Littoral). (A. Cvitanović, Ed.) (Vols. 1-6, Vol. 6). Zagreb: Školska knjiga. Everett, S. (2008). Beyond the visual gaze? The pursuit of an embodied experience through food tourism. Tourist Studies, 8(3), 337-358. http://dx.doi.org/10.1177/1468797608100594

Gardiner, A., \& Perkins, C. (2005). 'It's a sort of echo...': Sensory perception of the environment as an aid to tactile map design. British Journal of Visual Impairment, 23(2), 84-91. http://dx.doi.org/10.1177/02 64619605054780

Gibson, J. J. (1986). The ecological approach to visual perception. Hove, East Sussex; New York: Psychology Press.

Golledge, R. G. (1992). Place recognition and wayfinding: Making sense of space. Geoforum, 23(2), 199-214. http://dx.doi.org/10.1016/00167185(92)90017-X

Halmi, A. (1996). Kvalitativna metodologija u društvenim znanostima (Qualitative methodology in social sciences). Samobor: A. G. Matoš.

Hough, M. (1990). Out of place: Restoring identity to the regional landscape. New Haven; London: Yale University Press.

HRCroatia (2009, July 10). Kad srce kaze ljeto kaze Hrvatska (When heart says summer, it says Croatia). You Tube. Media sharing site. Available at http://www.youtube.com/watch?v=2cf_U9rRY4g

Hrdalo, I., Aničić, B., Pereković, P., Rechner, I., \& Andlar, G. (2008). Tipologija poljoprivrednih krajobraza dubrovačkog primorja kao osnova za usmjeravanje razvoja (The typology of the agricultural landscape of Dubrovačko Primorje as a basis for directing development). Journal of Central European Agriculture, 9(1), 77-94. 
DRUŠ. ISTRAŽ. ZAGREB GOD. 22 (2013), BR. 2, STR. $277-302$

KLJENAK, M. ET AL.: EXPERIENCING..
Ivanišević, G. (2002). Bogatstvo u zemlji, moru i zraku (The richness in the land, sea and air). Narodni zdravstveni list, 44(3), 5-6.

Kitchin, R. M., Blades, M., \& Golledge, R. G. (1997). Understanding spatial concepts at the geographic scale without the use of vision. Progress in Human Geography, 21(2), 225-242. http://dx.doi.org/10.1191/ 030913297668904166

Lewis, P. F. (1979). Axioms for reading the landscape: Some guides to the American scene. In Donald William Meinig (Ed.), The interpretation of ordinary landscapes: Geographical essays (pp. 11-32). New York; Oxford: Oxford University Press.

Lynch, K. (1960). The image of the city. Cambridge, Mass.; London, England: MIT Press.

Macpherson, H. (2006). Landscape's ocular centrism: And beyond? In B. Tress, G. Tress, G. Fry, \& P. Opdam (Eds.), From landscape research to landscape planning: Aspects of integration, education and application (Vol. 12, pp. 95-104). Dordrecht: Springer. Available at http://library.wur.nl/ ojs/index.php/frontis/issue/view/210

McHarg, I. L. (1992). Design with nature. New York [u.a.]: John Wiley \& Sons.

Meinig, D. W. (1979). Symbolic landscapes: Some idealizations of American communities. In Donald William Meinig (Ed.), The interpretation of ordinary landscapes: Geographical essays (pp. 164-192). New York; Oxford: Oxford University Press.

Mirošević, L. (2011). Tvorbeni elementi prostornih identiteta u Dalmaciji (Južnoj Hrvatskoj) (Formative elements of spatial identities in Dalmatia (Southern Croatia)). (Doctoral dissertation). University of Zadar, Zadar.

Mišetić, A. (1997). Socijalne značajke rive u životu grada. Primjer Splita (The social characteristics of riva in the life of a town (Split)). Društvena istraživanja, 6(1), 71-87.

Mišetić, A. (2004). Gradski rituali: retradicionalizacija društvenog života u hrvatskim gradovima nakon 1990. (Urban rituals: Retraditionalization of social life in Croatian cities after 1990). Zagreb: Hrvatska sveučilišna naklada.

Moore, N., \& Whelan, Y. (2007). Heritage, memory and the politics of identity: New perspectives on the cultural landscape. Aldershot, England: Ashgate Publishing, Ltd. Available at http://books.google.hr/books/ about/Heritage_Memory_and_the_Politics_of_Iden.html?id=dqD7I 8TVUnsC\&redir_esc $=\mathrm{y}$

Ndubisi, F. (2002). Ecological planning: A historical and comparative synthesis. Baltimore; London: Johns Hopkins University Press.

Nogué, J., \& Vicente, J. (2004). Landscape and national identity in Catalonia. Political Geography, 23(2), 113-132. http://dx.doi.org/10.1016/ j.polgeo.2003.09.005

Observatori del Paisatge de Catalunya (2009). Home page. Dossier: Soundscapes. Informational website. Available at http://www.catpaisatge.net/ dossiers/psonors/eng/index.php

Pallasmaa, J. (2005). The eyes of the skin: Architecture and the senses. Chichester, West Sussex: John Wiley \& Sons. 
DRUŠ. ISTRAŽ. ZAGREB GOD. 22 (2013), BR. 2 STR. 277-302

KLJENAK, M. ET AL: EXPERIENCING...
Paterson, M. (2007). The senses of touch: Haptics, affects and technologies. Oxford; New York: Berg. Available at http://books.google.hr/books? $\mathrm{id}=\mathrm{i} 4 \mathrm{mFY}$ aS95gC\&pg $=$ PA20\&dq $=$ Aristotle + five + senses\&ei $=$ OD b8T53QJ4OYzATE8_TgDw\&hl $=\mathrm{hr} \& \mathrm{~cd}=1 \# \mathrm{v}=$ onepage\&q=Aristotl e $\% 20$ five $\% 20$ senses $\& \mathrm{f}=$ false

Paterson, M. (2009). Haptic geographies: Ethnography, haptic knowledges and sensuous dispositions. Progress in Human Geography, 33(6), 766-788. http://dx.doi.org/10.1177/0309132509103155

Pink, S. (2009). Doing sensory ethnography (2012 Reprint.). Los Angeles; London; New Delhi; Singapore; Washington DC: Sage Publications.

Polic, M. (2007). Okoljska psihologija (Environmental psychology). Skripta, Ljubljana.

Povrzanović, M. (1991). Regionalni, lokalni i individualni identitet: primjer klapskog pjevanja (Regional, local and individual identity: Examples of klapa singing). In D. Rihtman-Auguštin (Ed.), Simboli identiteta: studije, eseji, građa (Symbols of identity: Papers, essays, materials) (pp. 105-120). Zagreb: Hrvatsko etnološko društvo.

Radica, B. (1971). Sredozemni povratak (Mediterranean return). Muenchen; Barcelona: Knjižnica Hrvatske revije.

Rodaway, P. (1994). Sensuous geographies: Body, sense, and place. London; New York: Routledge. http://dx.doi.org/10.4324/9780203306864

Skoko, B. (2004). Hrvatska (identitet, image i promocija) (Croatia (identity, image, promotion)). Zagreb: Školska knjiga.

Sopher, D. E. (1979). The landscape of home: Myth, experience, social meaning. In Donald William Meinig (Ed.), The interpretation of ordinary landscapes: Geographical essays (pp. 129-149). New York; Oxford: Oxford University Press.

Sui, D. Z. (2000). Visuality, aurality, and shifting metaphors of geographical thought in the late twentieth century. Annals of the Association of American Geographers, 90(2), 322-343. http://dx.doi.org/10. 1111/0004-5608.00197

The Landscape Observatory of Catalonia (2013). The Landscape Observatory - Activitat de l'The Landscape Observatory. Observatori del Paisatge. Informational website. Available at http://www.catpaisatge.net/ eng/activitat2.php? any $=2010$ \&tipus $=$ M\&idReg $=194$

Tkalac Verčič, A., Sinčić Ćorić, D., \& Pološki Vokić, N. (2011). Priručnik za metodologiju istraživačkog rada u društvenim istraživanjima: kako osmisliti, provesti i opisati znanstveno i stručno istraživanje (Handbook for research methodology - How to conceptualize, conduct and describe a scientific or expert research) (2. ed.). Zagreb: M.E.P.

Tuan, Y.-F. (1979). Thought and landscape: The eye and the mind's eye. In Donald William Meinig (Ed.), The interpretation of ordinary landscapes: Geographical essays (pp. 89-102). New York; Oxford: Oxford University Press.

Tuan, Y.-F. (1990). Topophilia: A study of environmental perception, attitudes, and values (Morningside edition). New York: Columbia University Press.

Visočnik, N. (2005). Food and identity in Japan. Etnološka istraživanja, $1(10), 7,19-18,28$. 
DRUŠ. ISTRAŽ. ZAGREB GOD. 22 (2013), BR. 2, STR. 277-302

KLJENAK, M. ET AL.: EXPERIENCING..
Zadar County Tourist Board (2009). Posebnosti: Morske orgulje (Special features: Sea organ). Zadar.hr. Informational website. Available at http:// www.zadar.hr/page.asp?pageID $=27 \&$ subID $=56$

\section{Doživjeti Dalmaciju: što čini osjetilni krajobrazni identitet dalmatinske regije?}

\author{
Maja KLJENAK \\ Zadar \\ Slavko KURDIJA \\ Fakultet društvenih znanosti, Ljubliana \\ Marko POLIČ \\ Filozofski fakultet, Ljubljana \\ Mojca GOLOBIČ \\ Biotehnički fakultet, Ljubliana
}

Okosnicu rada čini koncept krajobraznog identiteta promatran iz nove perspektive - perspektive pet osnovnih ljudskih osjetila: vida, sluha, njuha, opipa i okusa. Naime, krajobrazni (i općenito prostorni) identitet uglavnom se shvaća kao fenomen utemeljen na prepoznatliivim vizualnim karakteristikama. Međutim, sva je okolina multiosjetilni medii, bogat informacijama iz svih područja percepcije, a i čovjek je multiosjetilno biće i doživljava okolinu s više osjetila. U skladu s tim, ishodišna je pretpostavka rada ideja da se identifikacija čovjeka, odnosno društva, s prostorom ne odvija samo kroz interakciju s njezinim vizualnim nego i auditornim, olfaktornim, taktilnim, pa i gustatornim značajkama. Za područje istraživanja odabrana je dalmatinska regija. Primjenom metode analize sadržaja, na uzorcima lirskih pjesama te promotivnih (pretežno turističkih) materijala, cili je bio ispitati na kojim se obilježjima, vizualnim i nevizualnim, temelii društvena predodžba dalmatinskoga krajobraza. Rezultati upućuju na to da je krajobrazni identitet Dalmacije u osjetilnom smislu raznolik. Spoznaja o krajobraznom identitetu kao osjetilno višedimenzionalnoi pojavi otvara mnoga nova pitanja i mogućnosti na području krajobrazne teorije i prakse.

Ključne riječi: krajobraz, percepcija okoline, osjetila, osjetilni krajobrazni identitet, Dalmacija 